Volume 3, Number 2, 2017

\title{
Investigation of Sensor for Measurement of Rotation Angle of Sensitive Element in Rotational Paper Pulp Consistometer
}

\author{
Yevhen Pistun, Bohdan Kril, Oleksandr Romaniuk*, Oleksandr Kril \\ Lviv Polytechnic National University, 12 Bandery St., Lviv, Ukraine, 79013
}

Received: November 16, 2017. Revised: November 30, $2017 . \quad$ Accepted: December 06, 2017.

(c) 2017 The Authors. Published by Lviv Polytechnic National University.

\begin{abstract}
This paper presents the results of theoretical and experimental testing of an optical rotation angle sensor of rotational paper pulp consistency meter. It is suggested that a specialized device consisting of two discs with the diameter as large as possible should be applied in the rotational consistency meters. There are holes in the disks. One more optocoupler should be applied for registering the beginning of the signal processing of separate measurements in order to reduce the root-mean square error. The measurement cycle of the sensitive element rotation angle is conducted within a predetermined number of full turns of the main shaft. The research results can be applied during development of the paper pulp rotation consistency meters based on the compensation of the viscous friction torque and based on the direct measurement of the viscous friction by defining the rotation angle of the sensitive element.
\end{abstract}

Keywords: paper pulp consistency; measurement; rotation consistency meter; optical sensor; magneto-electric transducer.

\section{Definition of the scientific problem studied in the research}

Measurement of the paper pulp consistency on various stages of its preparation in tissue paper or cardboard manufacturing process can significantly influence the quality and the cost of production. Continuous control of the paper pulp consistency is usually performed by means of the mechanic method by defining the pulp viscosity [1,2]. There are two types of consistency meters that are based on this method: the rotational or mixer consistency meter, and the blade consistency meter. The rotational consistency meters can be of different design. However a common element for all of them is the device for measurement of the rotation angle of the sensitive element in relation to the rotation axe. During the improvement of such consistency meters and during development of new designs, it is important to increase the accuracy of measurement of the rotation angle for both rotation directions. This paper suggests a way of processing the signal from the optical sensor for the rotation angle measurement and discusses the obtained analytical ratios for processing of such signal.

\section{Analysis of the recent publications and research on the topic}

The paper pulp is a non-Newtonian fluid. Its consistency can be measured indirectly based on the viscosity. Commercially produced rotational devices are based on various designs that include a device to determine a rotation angle of a sensitive element.

Colimat 205-DD [3], Brookfield TT-100 [4] and similar devices that use an inductive converter to determine the rotation angle of the sensitive element are precise and reliable for non-polluted fluids. The abovementioned devices are viscometers and are used to measure the viscosity of organic fluids, first of all motor oils. Such devices are not

*Corresponding author. Email address: o.m.romaniuk@gmail.com

This paper should be cited as: Y. Pistun, B. Kril, O. Romaniuk, O. Kril. Investigation of sensor for measurement of rotation angle of sensitive element in rotational paper pulp consistometer. Energy Eng. Control Syst., 2017, Vol. 3, No. 2, pp. $73-80$. https://doi.org/10.23939/jeecs2017.02.073 
massive and they are not meant to work with fluids like paper pulp. The design of the applied inductive transducers of the sensitive element rotation angle is not suitable for a paper pulp consistency meter.

Other known designs of paper pulp consistency meters use optical sensors to measure the rotation angle of a sensitive element.

The design presented in [5] uses an optical measurer of the sensitive element rotation angle that consists of two discs with holes. One of the discs is fixed on the main shaft rotated by means of an engine and a belt transmission. The second disc is installed on the shaft of the sensitive element that is coaxially placed inside the main shaft. The shift of disks is proportional to the sensitive element rotation angle and is measured with another opto-isolator with an open optical channel. The scheme of direct measurement of viscous friction using the sensitive element rotation angle is implemented in the device.

The special structure is designed to measure paper pulp consistency and is provided in [6]. It is similar to the previous one, with the main shaft rotating powered by an engine and belt transmission, and similar optical converter of the sensitive element rotation angle. Measurement of paper pulp consistency is based on the angle of rotation of the sensitive element. The main shaft is additionally equipped with a propeller to move the paper pulp from stagnant pocket of the measuring cell.

Consistency meters similar to MEK-2300, MEK-2400 [7] use a compensation design where excursion of the rotation angle of a sensitive element is constantly compensated by an electromagnetic converter. The current power coming through the coil of the electromagnetic converter will be proportional to the friction torque and the associated paper pulp consistency. In this design the main shaft is rotating by means of the belt transmission powered by an asynchronous engine, and an additional propeller moves paper pulp from the stagnant pocket. Rotation angle of the sensitive element is measured by means of an optical sensor from two holed discs, one of which is installed on the main shaft and the other on the shaft of the sensitive element. Shift of the discs is measured by the width of impulses from the opto-isolator with the open optical channel.

The further designs have two drive units: one to rotate the main shaft of the device and the other to rotate the shaft with the sensitive element. These consistency meters are applying the compensation design: the power that the sensitive element shaft drive uses is proportional to the viscous friction torque. Description [8] employs an inductive sensor of the excursion of the rotation angle of a sensitive element the design of which is similar to an optical one. Engine rotors are located directly on the shafts, both the main one and the sensitive element shaft, and the belt transmission is not applied. The engines are powered by frequency converters. MEK-3000 [9] paper pulp consistency meters have a similar design. It also applies two drives, and disks with holes to measure the rotation angle of the sensitive element are located separately each having its own sensor.

Thus every reviewed paper pulp consistency meter design and viscometer have a sensor to measure the sensitive element rotation. It is either optical, or inductive or employs Hall elements. Improved design and methods of processing signals in such devices enables design of paper pulp consistency meters with enhanced metrological and operational performance.

\section{Purpose of the Article}

This article aims to improve the method of processing signals from the optical sensors measuring rotation angle of a sensitive element in paper pulp rotation consistency meters that can use both direct measurement of viscous friction torque and viscous friction torque compensation.

\section{Basic paper pulp consistency meter design that was used to study the device for measurement of the sensitive element rotation angle}

The study of a sensor measuring sensitive element rotation angle was conducted with a paper pulp consistency meter design provided in the Fig. 1.

The difference between this design and its analogues is that it employs a magnetoelectric transducer to compensate for the viscous friction torque impacting the disc-shaped sensitive element. The advantages of a magnetoelectric transducer as compared to an electromagnetic one are: the linear dependency of the conversion function; significantly higher ability to replicate; streamlined process to set the mechanical portion of the consistency meter, lighter details on the sensitive element shaft. In addition, the static characteristics of a magnetoelectric 
transducer are symmetrical in relation to the origin of coordinates which enables two-way rotation of the sensitive element to compensate for the influence of the paper pulp flow speed. The disadvantages include the high number of contact rings and brushes to lead current to the magnetoelectric transducer coils. However, such technical design is robust, and the service life of the connection assembly is commensurate to the service life of bearings and other mechanical details of the device.

The study results can also be applied for other designs of paper pulp rotation consistency meters, for example for designs with an electromagnetic transducer to compensate the viscous friction torque, or for designs measuring consistency by the rotation angle of the sensitive element and the torsion elastic element between the two shafts.

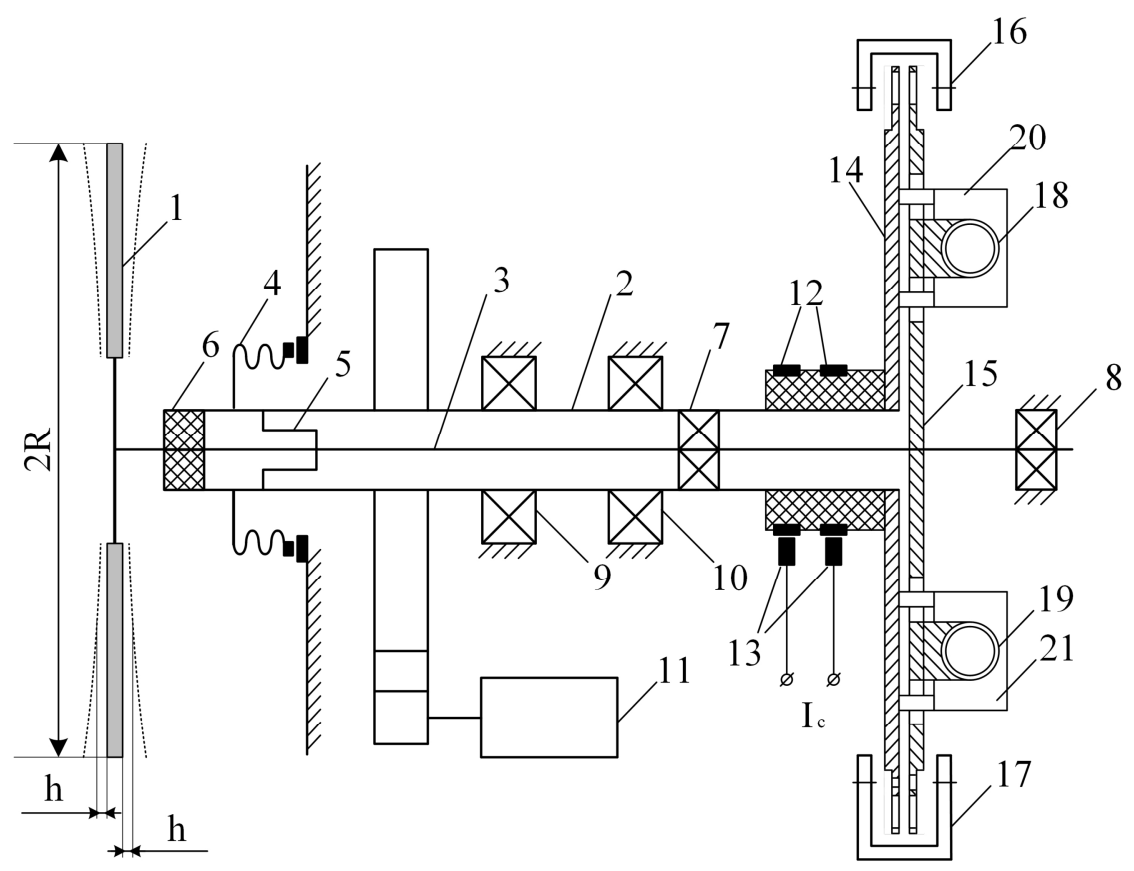

Fig.1. Design of the mechanical part of a rotation paper pulp consistency meter with magnetoelectric compensation of viscous friction: 1 - disk sensitive element; 2 - main hollow shaft of the device; 3 - sensitive element shaft; 4 - sealing of the main hollow shaft, consists of bellow valve and ring insertion made of tungsten carbide - cobalt alloy; 5 - elastic sealing of a longitudinal flute thin-walled tube; 6 - elastic sealing to protect the system 5; 7, 8 - bearings of the sensitive element shaft; 9,10 - bearings of the main hollow shaft; 11 - engine powered by a frequency converter; 12 - current-carrying rings; 13 - carbon fiber composite brushes; 14 - disk with cutouts in the main shaft; 15 - disk with cutouts on the sensitive element shaft; 16 - opto-isolator with open optical channel to measure shift of the disks 14 and 15; 17 - opto-isolator with open optical channel to establish a fixed starting moment;

18,19 - coils of the magnetoelectric transducer installed on the disk 15;20, 21 - magnetic systems installed on the disk 14.

Rotation paper pulp consistency meter in the Fig. 1 consists of a disk-shaped sensitive element 1 with wave-like prominences symmetrical in relation to the rotation direction, the main hollow shaft of the device 2 rotating on bearings 9 and 10 powered by an asynchronous engine 11 through a belt transmission. Inside the hollow shaft 1 , on the elastic sealing of a longitudinal flute thin-walled tube 5, and bearings 7 and 8 , there is the shaft 3 installed coaxially with the sensitive element 1 installed on it. On the paper pulp side the sealing 5 is closed with an elastic ring 6 , and there is a sealing 4 on the main shaft 2. Design of the magnetoelectric transducer and the discs with cutouts for measuring of the sensitive element rotation angle is integrated. Disk with cutouts 14 is installed on the shaft 2. Magnet systems 20 and 21 are installed on this disk. Disk 15 is of the same design and is installed on the shaft 3. Two aluminum frames with coil 18 and 19 are installed on this disk. Current-carrying rings 12 and brushes 13 are providing current for the coils 18 and 19. Rotation angle of the disks 14 and 15 is measured with an opto-isolator with open optical channel 16. Additional opto-isolator 17 is used to establish a fixed beginning of counting impulses from the opto-isolator 16 .

Measuring paper pulp consistency the main shaft and all elements installed on it are rotating with a specified angle rate that has been chosen for measurement. While viscous friction depends on the paper pulp consistency, it results in the torque that will impact the sensitive element 1 . This torque will make the sensitive element rotate at a 
certain angle in relation to the main shaft of the device. This angle is measured by the shift of the disk 15 against the disk 14 that is determined by the width of impulses produced by the opto-isolator 16 . The shift of the sensitive element rotation angle is compensated by a magnetoelectric transducer, and the current power coming through the coil of the electromagnetic transducer will be proportional to the viscous friction torque and the associated paper pulp consistency.

\subsection{Justification of the sensor design for measurement of the rotation angle in a sensitive element of the rotational paper pulp consistency meter}

Despite the broad variety of different designs of commercial incremental encoders for measurement of rotation angle and other rotation parameters, rotation paper pulp consistency meters use special sensor designs to measure the sensitive element rotation angle. This is resulting from the fact that the shaft 2 (Fig. 1) is rotating in bearings 9 and 10 with a large diameter $(D=85 \mathrm{~mm}, d=45 \mathrm{~mm}, 7209 \mathrm{~B})$ in order to ensure the mechanical robustness of the device and the required service life. Elements of bigger bearings have higher shifts and are operated in harder environment in rotation, therefore when shafts with such bearings dock with encoders, the rotation angle values fluctuate significantly resulting in decreased precision of measurement. Same effect is observed in other technical tasks, for example when determining the point of shredding in rotary scissors. The inductive sensor to measure the sensitive element rotation angle of viscometers $[3,4]$ designed for clear fluids is not suitable for a paper pulp consistency meter which is a heavier device due to the type of work to be performed.

Therefore the most suitable design of an optical sensor for rotational paper pulp consistency meters is the one with two equal disks with holes and of a largest diameter possible. One of the disks is installed on the main shaft and the other one on the shaft with the sensitive element. The opto-isolator with an open optical channel: a LED and a photodiode are measuring the shift of gaps that is changing as the disks move against each other.

The look of the sensor of rotation angle in a sensitive element of rotational paper pulp consistency meter that had been used in the study before the design was improved is available in the Fig. 2, it is a MEK-2400 [7]optical sensor of a paper pulp consistency meter.

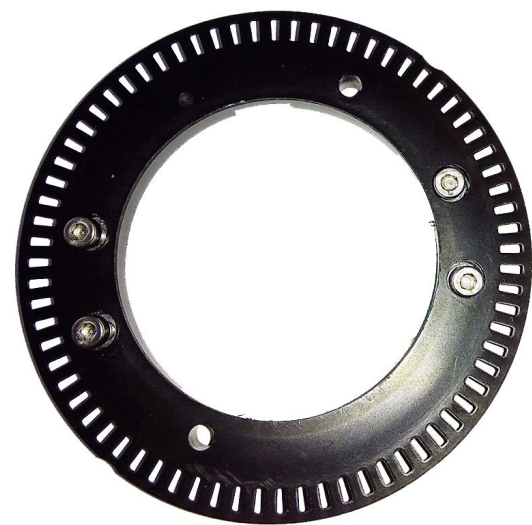

1

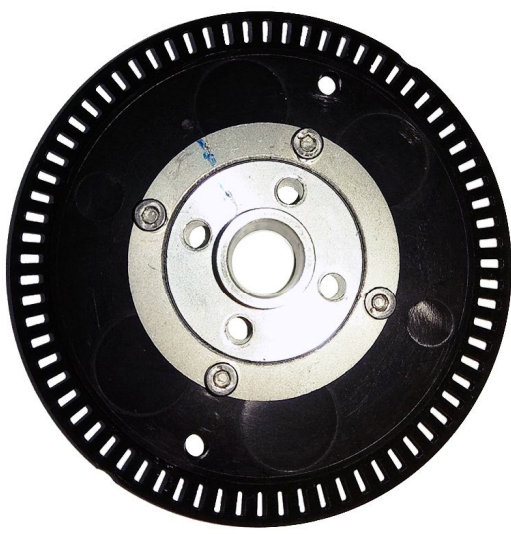

2

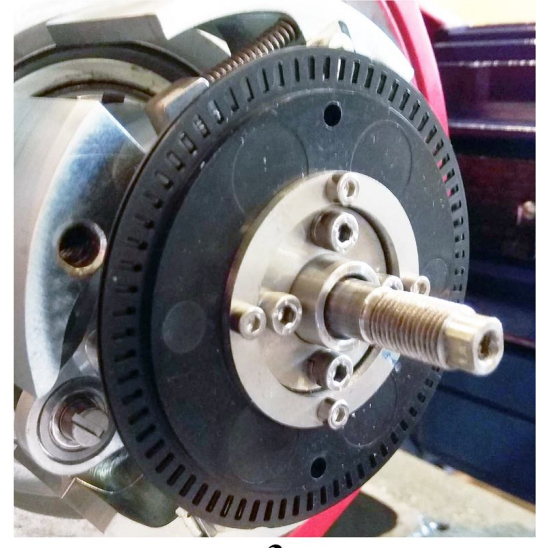

3

Fig.2. Design of the sensor for measurement of the rotation angle in a sensitive element of rotational consistency meter [7]: 1 - disk with holes installed on the main shaft of the device; 2 - disk with holes installed on the sensitive element shaft; 3 - optical sensor to determine the sensitive element rotation angle in a paper pulp consistency meter (without opto-isolators).

4.2. Description of the assembly to process the signal from the sensor of rotation angle in a sensitive element of rotational paper pulp consistency meter, study devices, study methodology

The diagram of the device for processing the signal from a sensor of rotation angle in a sensitive element of rotational consistency meter is presented in Fig.3. The same device supplied with a frequency meter was used to study an optical sensor for measuring the sensitive element rotation angle in a rotational paper pulp consistency meter.

The device functions as described below.

Depending on the rotation angle of the sensitive element shaft relative to the main shaft of the consistency meter, disk 2 shifts against disk 1 and the angle of overlap of the holes will change. In one rotation of the disks 1 and 2 the 
opto-isolator 3 records 72 rectangular impulses, their width depending on the rotation angle of the disk 2 against the disk 1. The way of initial placement of disk 2 against the disk 1 can result in decrease or increase of the width of impulses as the rotation angle of the sensitive element is increasing.

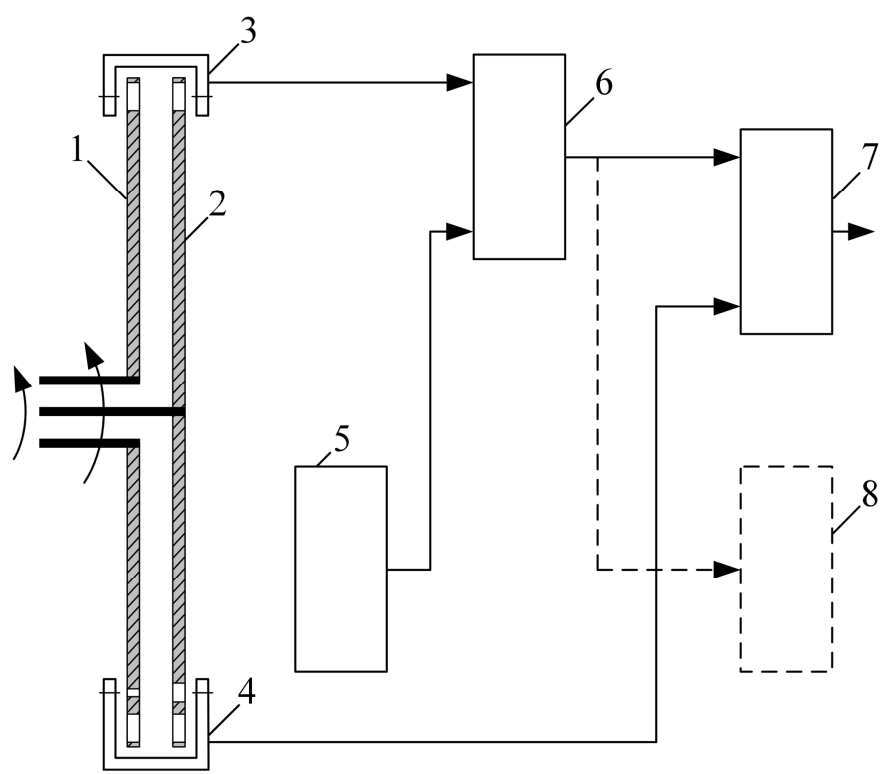

Fig.3. Diagram of the device for processing the signal from a sensor of rotation angle in a sensitive element of rotational consistency meter: 1 - disk with holes installed on the main shaft of the device; 2 - disk with holes installed on the sensitive element shaft; 3 - opto-isolator to determine the sensitive shift of the holes of disks 1 and 2; 4 - opto-isolator to establish a fixed start of measurement; 5 - crystal-controlled pulse oscillator with $50 \mathrm{kHz}$ frequency; 6 - matching logical element; 7 programmable logical controller with high-speed inputs; 8 - frequency meter.

The next task to be solved is measuring the width of impulses after the opto-isolator 3 . The easiest solution is to use a programmable logic controller if such impulses are filled with impulses with a significantly higher recorded frequency and counted.

Three ways to process signals have been studied and compared: 1 - counting impulses in a pack after the logical coincidence element 6 in a predetermined time $1 \mathrm{sec} ; 2$ - counting impulses in arbitrarily chosen successive 504 packs of impulses after the logical element 6 , that corresponds to 7 rotations of the main shaft of the device and timewise, for the selected rotation velocity of sensitive element rotation will be similar to $1 \mathrm{sec} ; 3$ - processing data similarly to No. 2, however beginning counting with the impulse from the opto-isolator 4.

The relative standard deviation of thirty successive measurements was used as a precision criterion for the optical sensor measuring the sensitive element rotation angle in a paper pulp consistency meter. The measurements were done with rotation of a consistency meter both in air and in water, and calculation of the relative standard deviation was reduced to the range of consistency meter measurement of $0-5 \%$ paper pulp consisting of a mix of corrugated fiberboard (about 50\%), office (25\%) and newspaper (25\%) paper.

\subsection{Results of the study and analysis of the obtained numerical values}

The design of a sensor of sensitive element rotation angle of a paper pulp consistency meter that was used in the experimental measurements is described in the Fig.2. Range of measurement of a sensitive element rotation angle -1 $+1^{\circ}$. The range of change of sensitive element rotation angle is smaller in compensation devices and varies from -0.4 to $+0.4^{\circ}$, meantime the torque caused by the sealing of the sensitive element shaft is ranging from -0.7 to +0.7 Newton.meter. The main shaft was powered by an asynchronous engine, and the exact number of rotations of an asynchronous engine in 1 minute was measured with the same optical sensor and if calculated for water equaled 1491 turns $/$ min. As the viscous friction torque was increasing to 1.25 Newton-meter, the number of engine rotations decreased to 1482 turns/minute, i.e. the relative change of numbers of turns was 0.6 and as such was not taken into consideration in further calculations. This change of number of rotations of an engine due to mechanical load is reproduced in unique fashion, however, it can change as the bearings wear. It is clear that to increase the accuracy of 
paper pulp consistency measurement and to increase the stability of device readings, the number of engine rotations can be stabilized with a higher degree of precision if an engine is powered by a frequency converter that is part of the closed system of regulating number of engine rotations.

The abovementioned number of engine rotations were matched by a number of rotations of the main shaft equal to $\omega=7.193$ and $\omega=7.15$ in 1 second respectively. At the same time the number of teeth of sheaves of the step-down gear train equals $Z_{1}=22$ and $Z_{2}=76$. The estimated quantity of impulses with $50 \mathrm{kHz}$ frequency in 72 packs in one turn of the main shaft changes from 0 to 2780 when the sensitive element rotation angle changes from $-1^{\circ}$ to $+1^{\circ}$.

The formula to calculate the number of impulses $N_{1}$ after the logic element 6 over the time $T$ is the following:

$$
N_{1}=\frac{m \cdot \alpha}{360^{\circ}} \cdot f_{G} \cdot T
$$

where $\alpha$ is the rotation angle of the disk 2 in relation to the disk $1 ; m$ is the number of holes in the disk, $m=72 ; f_{G}$ is the frequency of the crystal-controlled oscillator.

The formulas to calculate the number of impulses $N_{2}$ after the logic element 6 over one rotation of the sensitive element are as follows:

$$
N_{2}=\frac{m \cdot \alpha}{360^{\circ}} \cdot \frac{f_{G}}{\omega}, \quad \omega=\frac{n}{60} \cdot \frac{Z_{1}}{Z_{2}}
$$

where $\omega$ is the frequency of sensitive element rotation; $n$ is the number of rotations over 1 minute; $Z_{l}$ is the number of sheave teeth on the engine shaft; $Z_{2}$ is the number of sheave teeth on the main shaft of the consistency meter.

The first experiment tested the relative standard deviation of the number of impulses after the logic element 6 over 1 second with the sensitive element rotating in air and in water, and the measurement range reduced to $0-5 \%$ of paper pulp, which contents are provided in paragraph 4.2. The estimated quantity of impulses with change of sensitive element rotation angle within the range of $-1^{\circ}-+1^{\circ}$ from 0 to 20,000 . The results are provided in Table 1 .

Table 1. Results of an experimental study of a sensor for measurement of a sensitive element rotation angle in a paper pulp consistency meter for calculation of impulses after the logical element over 1 second.

\begin{tabular}{|c|c|c|c|c|c|c|}
\hline $\begin{array}{c}\text { Type of the } \\
\text { sensitive element }\end{array}$ & Air & Water, $20^{\circ} \mathrm{C}$ & $\begin{array}{c}\text { Water, } 20^{\circ} \mathrm{C}, \text { with } \\
\text { torque } \\
\text { compensation }\end{array}$ & Air & Water, 20 ${ }^{\circ} \mathrm{C}$ & $\begin{array}{c}\text { Water, 20 } \\
\text { torque with } \\
\text { compensation }\end{array}$ \\
\hline $\begin{array}{c}\text { Medium } \\
\text { Mean value of } \\
\text { number of } \\
\text { impulses }\end{array}$ & 14393 & 13868 & 14396 & 14373 & 13685 & 14416 \\
\hline S, impulses & 22 & 27 & 23 & 26 & 21 & 23 \\
\hline $\begin{array}{c}\sigma, \% \text { reduced to } \\
\text { the measurement } \\
\text { range }\end{array}$ & 0.81 & 1.0 & 0.85 & 0.74 & 0.6 & 0.66 \\
\hline
\end{tabular}

It was assumed that mechanical factors will influence the results of measurements, for example such factors as presence of a belt transmission, friction of the main shaft, etc. Therefore the time chosen to calculate impulses was 10 seconds, although such time of averaging the sensitive element rotation angle measurement is too long for real devices. The estimated quantity of impulses will be within the range from 0 to 200,000. The results are provided in Table 2.

The relative standard deviations of the numbers of impulses calculated over 10 seconds are smaller than when calculated over 1 second. This proves that mechanical factors influence the operation of a sensor for measurement of a sensitive element rotation angle. Such influence can be reduced by using direct drive from a servo actuator as it was done in consistency meter designs described on [8] and [9].

The next experiment consisted of calculating 504 packs of impulses after a logic element 6 that in time was close to processing results of measurements over $1 \mathrm{sec}$ used in the previous method and equals 7 full turns of the main shaft. The results are provided in Table 3 . 
Table 2. Results of an experimental study of a sensor for measurement of a sensitive element rotation angle in a paper pulp consistency meter for calculation of impulses after the logical element over 10 seconds period.

\begin{tabular}{|c|c|c|c|c|c|c|}
\hline $\begin{array}{c}\text { Type of the } \\
\text { sensitive element }\end{array}$ & \multicolumn{3}{|c|}{ Disk $\varnothing 186 \mathrm{~mm}$} & \multicolumn{3}{|c|}{ Type B, MEK-2300 [7] } \\
\hline Medium & Air & Water, $20^{\circ} \mathrm{C}$ & $\begin{array}{c}\text { Water, } 20^{\circ} \mathrm{C} \text {, with } \\
\text { torque } \\
\text { compensation }\end{array}$ & Air & Water, $20^{\circ} \mathrm{C}$ & $\begin{array}{c}\text { Water, } 20^{\circ} \mathrm{C} \text {, with } \\
\text { torque } \\
\text { compensation }\end{array}$ \\
\hline $\begin{array}{c}\text { Mean value of } \\
\text { number of } \\
\text { impulses }\end{array}$ & 143747 & 138327 & 144128 & 142961 & 135962 & 143695 \\
\hline $\mathrm{S}$, impulses & 77 & 127 & 58 & 88 & 170 & 112 \\
\hline $\begin{array}{c}\sigma, \% \text { reduced to } \\
\text { the measurement } \\
\text { range }\end{array}$ & 0.29 & 0.47 & 0.21 & 0.25 & 0.49 & 0.32 \\
\hline
\end{tabular}

Table 3. Results of an experimental study of a sensor for measurement of a sensitive element rotation angle in a paper pulp consistency meter for calculation of 504 packs of impulses after the logical element.

\begin{tabular}{|c|c|c|c|c|c|c|}
\hline $\begin{array}{c}\text { Type of the } \\
\text { sensitive element }\end{array}$ & \multicolumn{3}{|c|}{ Disk $\varnothing 186 \mathrm{~mm}$} & \multicolumn{3}{c|}{ Type B, MEK-2300 [7] } \\
\hline Medium & Air & Water, $20^{\circ} \mathrm{C}$ & $\begin{array}{c}\text { Water, } 20^{\circ} \mathrm{C}, \text { with } \\
\text { torque } \\
\text { compensation }\end{array}$ & Air & Water, 20 ${ }^{\circ} \mathrm{C}$ & $\begin{array}{c}\text { Water, 20 } \\
\text { torque } \text {, with } \\
\text { compensation }\end{array}$ \\
\hline $\begin{array}{c}\text { Mean value of } \\
\text { number of } \\
\text { impulses }\end{array}$ & 14185 & 13670 & 14178 & 14167 & 13496 & 14211 \\
\hline S, impulses & 20 & 23 & 19 & 24 & 17 & 18 \\
\hline $\begin{array}{c}\sigma, \% \text { reduced to } \\
\text { the measurement } \\
\text { range }\end{array}$ & 0.77 & 0.89 & 0.74 & 0.72 & 0.51 & 0.54 \\
\hline
\end{tabular}

Relative standard deviations of measurement for this experiment are smaller compared to the results provided in the Table 1. Thus, this method of processing signals on the value of sensitive element rotation angle has more precision.

The next assumption was that establishing a fixed starting point to calculate impulses in packs after the impulse from the additional opto-isolator 4 should also decrease the relative standard deviation of the measurement results. An experiment was conducted similarly to the previous one, however it had an established fixed beginning of of calculation in the same place of disk 1 after impulse from opto-isolator 4 . The results are provided in Table 4.

Table 4. Results of an experimental study of a sensor for measurement of a sensitive element rotation angle in a paper pulp consistency meter for calculation of 504 packs of impulses after the logical element with an established fixed counting point.

\begin{tabular}{|c|c|c|c|c|c|c|}
\hline $\begin{array}{c}\text { Type of the } \\
\text { sensitive element }\end{array}$ & Air & Water, $20^{\circ} \mathrm{C}$ & $\begin{array}{c}\text { Water, 20 } \\
\text { torque } \mathrm{C} \text {, with } \\
\text { compensation }\end{array}$ & Air & Water, 20 C & $\begin{array}{c}\text { Water, } 20^{\circ} \mathrm{C}, \text { with } \\
\text { torque compensation }\end{array}$ \\
\hline Medium & 14154 & 13662 & 14157 & 14164 & 13486 \\
\hline $\begin{array}{c}\text { Mean value of } \\
\text { number of } \\
\text { impulses }\end{array}$ & 14 & 12 & 11 & 12 & 14205 \\
\hline $\begin{array}{c}\text { S, impulses } \\
\text { the meduced to } \\
\text { rasurge }\end{array}$ & 0.54 & 0.47 & 0.43 & 0.36 & 13 & 0.45 \\
\hline
\end{tabular}

Results provided in the Table 4 confirm the positive result of establishing a fixed calculation point for calculating impulses after the signal from the additional opto-isolator 4. This method to process a signal from the sensor measuring sensitive element rotation angle in paper pulp consistency meters was chosen as the most precise for the device.

\section{Presentation and discussion of the research results}

Results of the research have shown that the design with a magneto-electric compensator of viscous friction that is designed as an integrated device with an optical sensor to measure the sensitive element deviation angle is the most advantageous for paper pulp consistency meters. This design is also very convenient for technical realization and 
adjustments. It is also suggested to measure the sensitive element rotation angle value over a predetermined number of full turns of disks with holes that are installed on the device shafts, where to measure the signal from the main opto-isolator an initial impulse should be provided by an additional opto-isolator.

The suggested method of processing signals from the optical sensors measuring rotation angle of a sensitive element in paper pulp rotation consistency meters can be used for consistency meter designs with direct measurement of viscous friction torque.

\title{
6. Conclusion
}

This paper shows that paper pulp rotation consistency meters can employ only specialized sensors to measure the sensitive element rotation angle. Diameter of disks with holes in such devices should be as large as possible in relation to the dimensions of the device. It is reasonable to use another opto-isolator in order to start the counting and processing of the signal from the same point of the disks with holes, where the processing cycle should fit into the integer of full rotations of the main shaft of the device. Such solutions reduce the standard deviation of measurement results for commensurate averaging times and thus increase precision of measurement of sensitive element rotation angle in consistency meters. Results obtained are applicable for many designs of rotation paper pulp consistency meters.

\section{References}

[1] Michael H. Waller (1993) A tutorial on the measurement of paper stock consistency. ISA Transactions 32, $277-282$.

[2] Steffe J.F. (1996) Rheological Methods in Food process Engineering. Second edition. Freeman press, East Lansing, MI, USA 418p.

[3] Covimat 205. URL: http://www.prorheo.de/fileadmin/user_upload/pdfs/Covimat_205_DD_zF.pdf

[4] TT-100 Viscometer e for In-line System Applications. URL: http:/www.brookfieldengineering.com/products/viscometers/in-line-processviscometers/tt-100-viscometer

[5] Ekhard Preikschat (1997) Rotating consistency transmitter impeller and method. US Patent No. 5684247.

[6] JT-Tieto Oy \& Marjo Nygård (2010) Metso Rotating Consistency Transmitter. Installation \& Owner's Manual K09157 V1.0 EN Metso Automation Inc. Documentation. www.metso.com/automation

[7] MEK-2300 with JCT-1100 User manual (2002) BTG Pulp and Paper Technology AB, Säffle, Sweden.

[8] Andersson N., Kullander J., Lundberg P., Adrian P. (2012) Phase Controller for a Dual Motor Torque Detecting Device. US Patent No.: US $8171776 \mathrm{~B} 2$

[9] MEK-3000 TwinTorque URL:https://www.btg.com/en/products/products-by-type/inline-instrumentation/consistency/consistency-detail/155/

\section{Дослідження давача для вимірювання кута повороту чутливого елемента ротаційного концентратоміра паперової пульпи}

\author{
Євген Пістун, Богдан Кріль, Олександр Романюк*, Олександр Кріль \\ Національний університет «Львівська політехніка», вул. С. Бандери, 12, Львів, 79013, Украӥна
}

\begin{abstract}
Анотація
Розглядаються результати теоретичного та експериментального дослідження оптичного давача для вимірювання кута повороту чутливого елемента ротаційного концентратоміра паперової пульпи. Стверджується, що для ротаційних концентратомірів має застосовуватись спеціалізований пристрій 3 двох дисків максимально можливого діаметру з прорізами по колу, а для зменшення середньоквадратичного відхилення результатів окремих вимірювань доцільно застосувати ще одну оптопару для фіксації початку обробки сигналу. Весь цикл вимірювання кута повороту чутливого елемента проводиться за фіксовану кількість повних обертів основного вала приладу. Результати дослідження можуть бути використані при розробці ротаційних концентратомірів паперової пульпи за схемами 3 компенсацією моменту в'язкісного тертя та за схемами 3 прямим вимірюванням моменту в'язкісного тертя за кутом повороту чутливого елемента.
\end{abstract}

Ключові слова: вимірювання; концентрація паперової пульпи; ротаційний концентратомір; оптичний давач; магнітоелектричний перетворювач. 